\title{
Anthropozoic impact on the floristic biodiversity in the area of Beni Saf (Algeria)
}

\author{
Sidi Mohammed Merioua ${ }^{1^{*}}$, Abdelhakim Seladji $^{2}$, Noury Benabadji $^{3}$ \\ ${ }^{1}$ University Center of Tissemsilt, Tissemsilt, Algeria; ${ }^{*}$ Corresponding Author: sm.merioua@gmail.com \\ ${ }^{2}$ National Institute of Forestry Research Station of Tlemcen, Tlemcen, Algeria \\ ${ }^{3}$ University of Tlemcen, Tlemcen, Algeria
}

Received 9 April 2013; revised 22 May 2013; accepted 27 June 2013

Copyright (C) 2013 Sidi Mohammed Merioua et al. This is an open access article distributed under the Creative Commons Attribution License, which permits unrestricted use, distribution, and reproduction in any medium, provided the original work is properly cited.

\begin{abstract}
The degradation of the natural resources in Algeria nowadays remains a major constraint for the agrosilvopastoral development. Indeed, the area of Beni Saf is confronted with many problems such as the anthropozoic pressure which does not make it possible to keep balance between the exploitation of the natural resources and their regenerations in time and space. Following the example results obtained through a floristic study by the factorial analysis of correspondences ( $F$ A C), concerning the identification of anthropozoogenes species such as: Chamaerops humilis, Asphodelus microcarpus, Withania frutescens, Calycotome spinosa, Asparagus albus; furthermore, the calculation of the disturbance index which marks the rate of therophytisation which is about $68 \%$, that one finds it very high. These indices show a disturbance and an imbalance of the plant formation of the zone of study, caused by the high anthropozoogene pressure. Vis-a-vis this threat, it is essential to propose a possibility of intervention for a durable management of these spaces.
\end{abstract}

Keywords: Biodiversity; Geographical Information System; Factorial Analysis of Correspondences; Anthropozoïc Impact; Beni Saf (Algeria)

\section{INTRODUCTION}

In the Mediterranean region, the multiple paleogeographic events and the contrasted climatic cycles also allowed the emergence of this unusually high biodiversity [1]. In the South and the East of the Mediterranean, the ecosystems are always intensively used by the man. Because of the considerable population growth, there has been acceleration during the three last decades of the use of the natural resources which often exceeds their capacities of renewal [2].

The north of Algeria is subject to strong pressures of men and cattle that generated a severe impoverishment of the soil and vegetable cover [3]. The anthropozoïc factors play a major role in the organization of the vegetation structures. Indeed, the population growth rate, especially rural, determined a radical transformation of the use of the environment. Deforestation, dematorralisation, anarchic cuts, uncontrolled cultures' settings and excessive overgrazing, deeply disturbed ecological balances which existed twenty years ago [4].

In Algeria, especially in Beni Saf, the anthropisation is remarkable. We notice several causes of deforestation which come into play: the conversion of forest surfaces to the profit of other destinations in particular, of the pasture and the field crops. In addition to the demographic pressure which is increasingly important, this is primarily related to the migrations, leading to the reduction of forest spaces, and disturbing the ecosystems.

The objective of this work is to determine the impact of the anthropozoic actions on the floristic biodiversity in order to highlight the possibilities of intervention for a better management of this weakened ecosystem.

\section{MATERIALS AND METHODS}

\subsection{Materials}

\subsubsection{State of the Vegetable Formations}

The zone of study covers an area of $6162 \mathrm{Ha}$. It is located at the level of the commune of BeniSaf on the North-western littoral of Algeria (Figure 1). The commune's population is estimated at approximately 43802 inhabitants and an average density of $715 \mathrm{per} / \mathrm{km}^{2}$. Most of it, approximately $80 \%$, concentrates in the town of Beni Saf. The active population (between 20 and 64 years old) of the commune lives mainly on agriculture. 


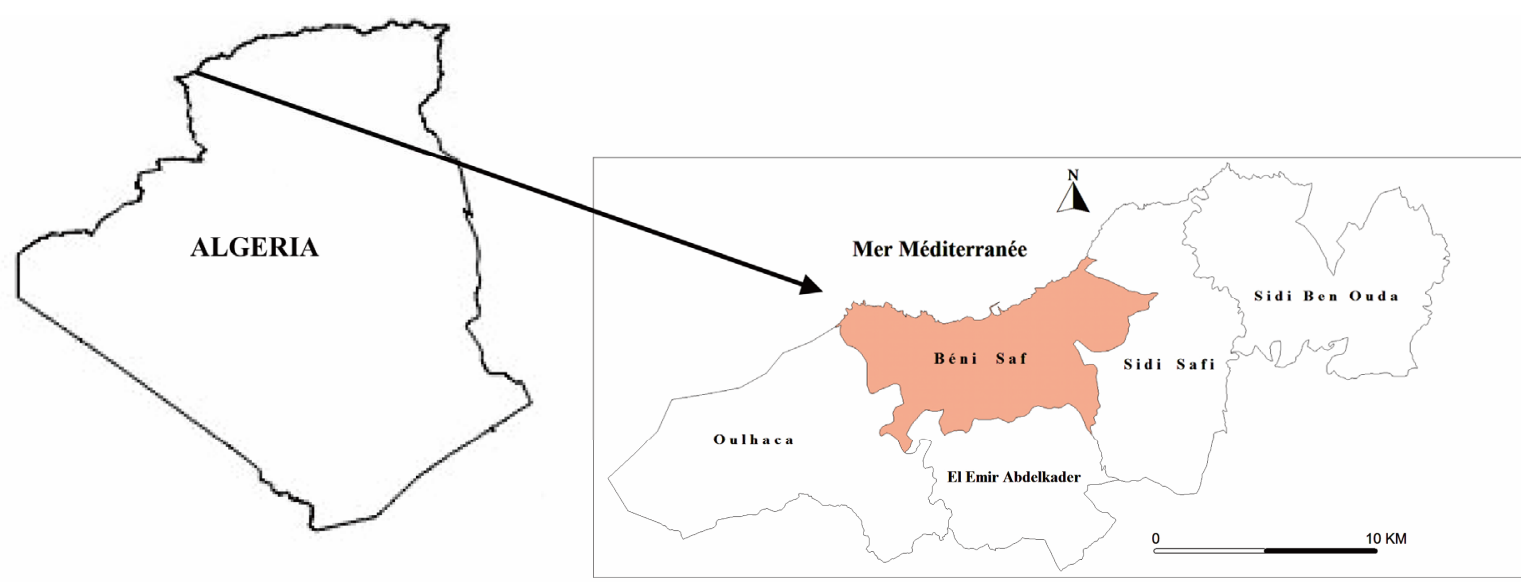

Figure 1. Location map of the study area.

This area is characterized by two types of reliefs: the massif of Beni Saf which culminates in its central part with $409 \mathrm{~m}$ in Skhouna mount and the valley of Tafna, on its right bank with a relatively flat topography. It extends on the Western end of the zone of study.

The forest capital of the region of Beni Saf extends on a surface of $2843.8 \mathrm{Ha}$, that is to say $46.15 \%$ of the total surface area of the commune (Figure 2). The majority ofthe vegetable settlement, are generally artificial forest formations resulting from afforestation carried out in 1945, 1960, 1970 and 1980, to fight against the floods and the subsidence. The most used species in these afforestation's are Pinus halepensis and the Eucalyptus cameldulensis, which often replaced the degraded vegetation, made up of matorrals (pine plantations) more or less dense and based on thermophilous species, under a pluviometer which varies between 350 and $400 \mathrm{~mm}$, these taxa tolerate the soils rich in limestone. The floris tic composition is very known by the following species: Pinus halepensis, Ceratonia siliqua, Olea europea ssp oléastre, Pistacia lentiscus, Asparagus acutifolius, Calycotome spinosa, Phillyrea angustifolia, Ampelodesma mauritanicum, Chamaerops humilis, etc. The herbaceous layer is dominated by, Cistus albidus, Cistus monspeliensis, Rosmarinus officinalis, Lavandula dentata, Lavandula stoechas, Medicago arborea, Withania frutescens, Helianthemum helianthemoides, Lonicera implexa, etc. [5].

\subsubsection{Anthropozoic Action}

The pasture in Algerian forests is old; it eliminates by chattering the herbaceous layer and young regenerations, and reduces the floristic diversity. The human activity in the area of Beni Saf, is generally related to the extension of the agglomerations and agricultural spaces the detriment of forest spaces. Thus, the overgrazing and the clearing, lead to the degradation of vegetable cover and accentuate the phenomenon of erosion.

Bouazza and Benabadji [6], specify that overgrazing modifies the floristic composition considerably. Animals choose the species and consequently they impose on the consumable biomass offered an important selective action. During this last decade, the area of Beni Saf knew the settlement of several families of semi nomads with their herds of sheep and bovines, having occupied the majority of farming lands, and practicingan extensive breeding. The overgrazing involves the reduction of the vegetable cover of the long-lived species and of their phytomass which thus opens the door with the processes of degradation [7].

Indeed, the pasture in this area is carried out during all the year. In summer, the herds occupy the agricultural lands after the harvest, and during the rest of the year, they graze in the forests. In front of this situation, overgrazing became increasingly dramatic, simultaneously with the results which were collected lately in particular: an imbalance in the floristic composition, a regression of the vegetable carpet, a destruction of the surface horizons, an erosion of the ground, an absence of the natural regeneration of the woody vegetation, and an occupation of the natural environments by the thérophytes (40\%) [5].

In the zone of study, there is an exponential increase in the heads of cattle (Total sheep is 15890 and total bovines is 1030), which led in a few decades to a dramatic and often irreversible regression of the vegetable cover. This quasi permanent overgrazing has led to the invasion of forests by the thérophytes species.

\subsubsection{Fires}

The plant population of the area of Beni Saf, are very susceptible to fire. This is directly related to various factors which influence their vulnerabilities (Geography, climate, the floristic composition and the anthropic action). According to Delabraze and Valette [8], Houerou [9], Tatoni and Barbero [10], the fires constitute a major disturbance of the Mediterranean landscapes. They are related to the intense anthropic pressures, to the character 


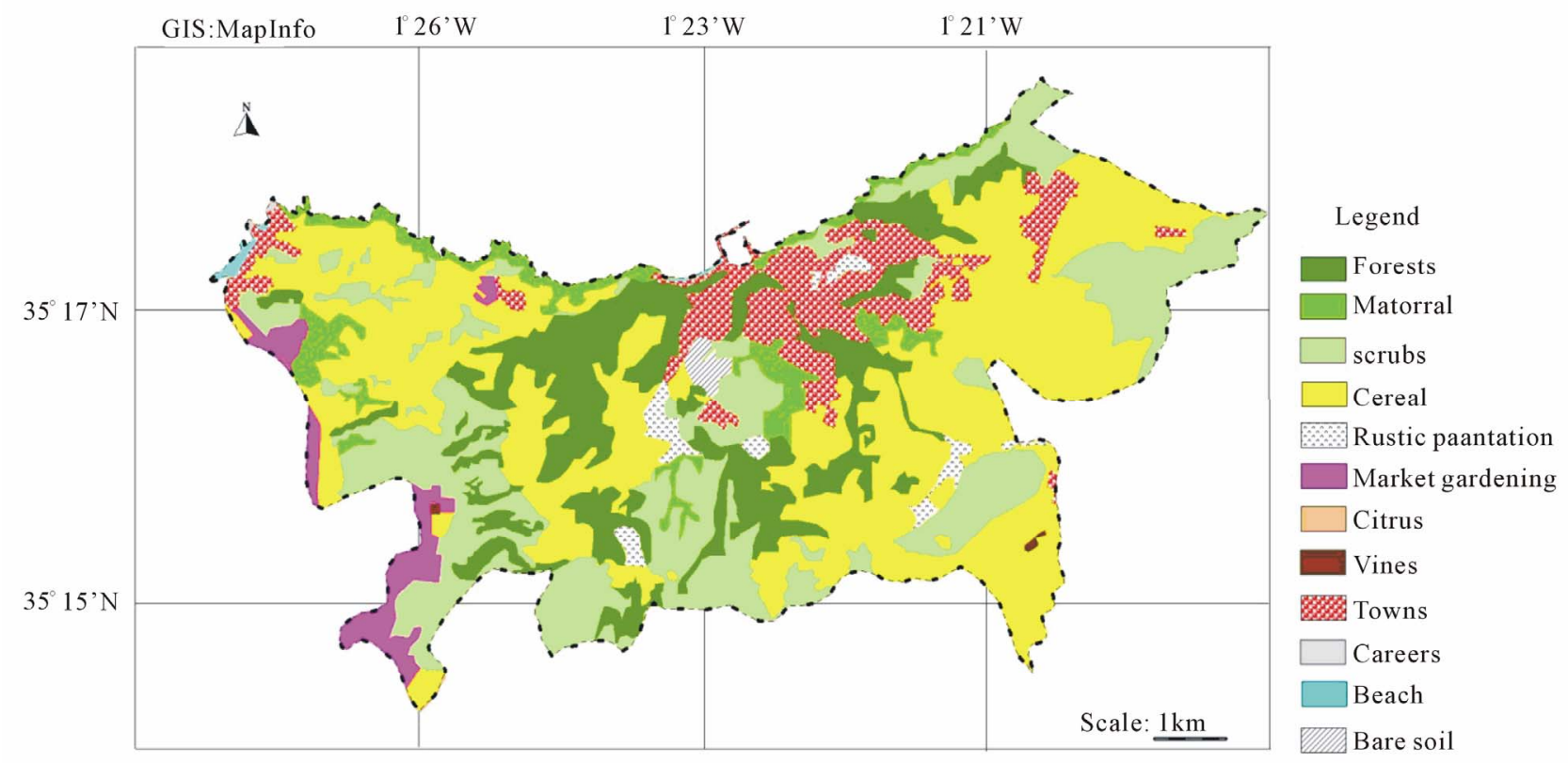

Projection Lambert V.L.U Northern Algeria

Figure 2. Map of land use in the area of Beni Saf (year 2004) source: Merioua, (2007).

xerophytic, and pyrophytic of the vegetation. Thus, the dominance of the thérophytes in the natural environments constitutes an important combustible mass in summer and facilitates the spread of fires [5].

Fires and the clearings left a strong imprint on the aspect of the natural environment of the area of Beni Saf, especially in the South and the East of the area. A large surface of forests and undergrowth were transformed into pastures and fields of cereals.

\subsection{Methodology}

The great heterogeneity of vegetable cover in the area of Beni Saf, made us reject the systematic inventory, in spite of its effectiveness, to be replaced by the stratified random inventory. This consists in sitting stations of floristic statements, where the plant population is homogeneous according to phytoecological transects.

According to Pardé and Bouchon [11], the advantage of stratified sampling takes account of the variability of the vegetation. The same sampling was used by Frontier [12] in the inventory of the vegetation, carried out by the method of Braun Blanquet [13]. Several investigations were programmed on the ground, with an aim of better knowing the existing vegetable formations and to identify the principal homogeneous zones in the area. Inside each zone, we chose a station which represents average ecological conditions, in which we can carry out floristic surveys, according to the method of the coefficients of abundance-dominance of Braun-Blanquet and to acquire various information on the characteristics of the natural environment in particular the localization of the site, the exposure, the slope, the presence of the effects of erosion, and the rate of covering... etc. These data enabled us to characterize five stations in the area.

Gehu [14] and Gounot [15] described the size and the shape of the statement. They derive from these requirements of homogeneity; we can say that in the Mediterranean region, the surface of the statement varies from 100 to $300 \mathrm{~m}^{2}$ in forest, and 50 with $100 \mathrm{~m}^{2}$ in the matorrals and a few square meters in the lawns. In the area of Beni Saf, the surface of $100 \mathrm{~m}^{2}$ appears sufficiently representative of the minimal surface of the vegetable formations. Regular visits during the season of vegetation (from February to October, in order to count the species of post-winter with autumnal), during which the whole of the site was prospected several times in order to establish a complete list of species and to identify anthropozoogenes species.

The floristic study by the correspondence analysis, also relates to the analysis of the vegetable communities in the zone of study. However, the statistical processing is a tool which can help us to determine some ecological and anthropic factors which govern the floristic composition of these vegetable populations, characterized by a high floristic diversity. This type of analysis (statistical), which showed its relevance in phytosociology and vegetable ecology, makes it possible to study the possible relations which are established between discontinuous and no quantitative variables [16].

For data processing of the floristic data, a code with four letters and a number is assigned to each one of taxa which were recorded in the area of Beni Saf. The first 
letter indicates the kind, the three other letters which follow, indicate the first letters of the species. The number presents the order of taxa in Table 1. Example: Acacia cyanophilla, is coded as follows: A-cya 1. Indeed, we used the method of the applied technique, the factorial analysis of correspondences, assisted by the software "Minitab 12". This type of treatment, whose mathematical bases are exposed in the thesis of Cordier [17] and the works like those of Benzekri [18], Fenelon [19], etc. has been classically used, since many years [20,21].

The treatment was carried out at the Laboratory of ecology of Tlemcen University (Algeria). We carried out the analysis of 50 statements from the totality of species (111). In these treatments, only the character "presenceabsence" of the species was considered, since the aim was the discrimination and the characterization of the species inventoried in the zone of study.

For the whole of these treatments, the symbols of the coefficient of abundance-dominance cannot be directly exploited. "+" not being a value, it was replaced by the number "0.5” (Table 1).

The cloud "points lines" or of "points columns" is stretched along a privileged direction which corresponds to the factorial axis of the analysis. Each factorial axis is characterized by an eigenvalue which reflects the inertia of the cloud point along the axis. The rate of inertia represents the percentage of the axis in the total inertia of the cloud. This eigenvalue and the rate of inertia are all higher than the cloud point. It is well structured along a factorial axis [22].

Benzecri [18] states that there is no doubt that the validity of a first axis have more than $50 \%$ of rate of inertia. The coordinates of the points (species) are given for each factorial axis, after projection of the cloud points obtained. In practice, the graphical representation occurs only on the first factorial axes, the most explanatory of the structure of the cloud points. We limited to the clouds of the points lines, corresponding to the plant species.

\section{Results and Interpretations}

The zone of Beni Saf, as the entire Mediterranean region is characterized by a very important biodiversity in terms of flora. We identified 111 species, which largely consists of the thérophytes, which represent $41 \%$ of all the existing vegetation (Table 2). Stebbins [23], Stebbins and Major [24], these authors announced the therophytes richness of the Mediterranean region and in particular the Maghreb, short-cycle species, which are adapted to the aridity of the climate and in particular to the summer hy-

Table 1. Coding of the coefficient of abundance-dominance.

\begin{tabular}{cccccccc}
\hline Coefficients of abudance-dominance & Absence & + & 1 & 2 & 3 & 4 & 5 \\
\hline Coefficients used & 0 & 0.5 & 1 & 2 & 3 & 4 & 5 \\
\hline
\end{tabular}

Table 2. Biological type.

\begin{tabular}{ccc}
\hline Biological type & Number of species & Rate \\
\hline Thérophytes & 46 & $41 \%$ \\
Chaméphytes & 29 & $26 \%$ \\
Phanérophytes & 16 & $14 \%$ \\
Hémicryptophytes & 11 & $10 \%$ \\
Géophytes & 9 & $8 \%$ \\
\hline
\end{tabular}

drous stress.

Also, Sauvage [25], Gaussen [26], Negro [27], Daget [28], Barbero et al. [4], Quézel [29], found that this therophytisation is an ultimate stage of the degradation of the vegetation. Loisel et al. [30] established a formula called index of disturbance, which quantifies the therophytisation of the natural environments.

$$
I P=\frac{\text { Number of Chamaephyte }+ \text { number of Thérophyte }}{\text { full number of the spicies }}
$$

The disturbance index (IP) of the zone of study BeniSaf is around $68 \%$, we find it important. This shows a disturbance and an imbalance of the vegetable population caused by the high anthropozoogene pressure. Furthermore, El Hamrouni [31], after a study of vegetation "forest and meadow forest" in Tunisia, found a rate of $70 \%$ of therophytisation. The same author concluded that this index is high.

The area of Beni Saf, is populated by 40 families (Figure 3). The compositae and the poaceae dominate the flora, with a rate of $14 \%$ for the first family, and $12 \%$ for the second. Lamiaceae, Papilionaceae, each one represents $7 \%$, Liliaceae $6 \%$, Apiaceae $5 \%$. The rest of the families, is composed of Cistaceae, Cruciferae, Euphorbiaceae, Plantaginaceae, Renonculaceae, represents a rate of $3 \%$ for each one. Chénopodiaceae, Cupressaceae, Cynareae, Fabaceae, Malvaceae, Myrtaceae, Oxalidaceae, Résédaceae, Rosaceae, account for approximately $2 \%$ each one. The following families represent a low rate approximately 1\%, including: Borraginaceae, Brassicaceae, Alsinoideae, Araliaceae, Astéraceae, Mimoseae, Oléaceae, Palmaceae, etc.

The correspondence analysis (Table 3) makes it possible to highlight the relations between the inventoried species and their environment that they occupy it (Figures 4-6).

\subsection{Eigenvalues and Rate of Inertia}

It is noticed that the eigenvalues and the rates of inertia are important (Table 4). Thus, we can explain the relations between the environment and the vegetation from the processed variables. 


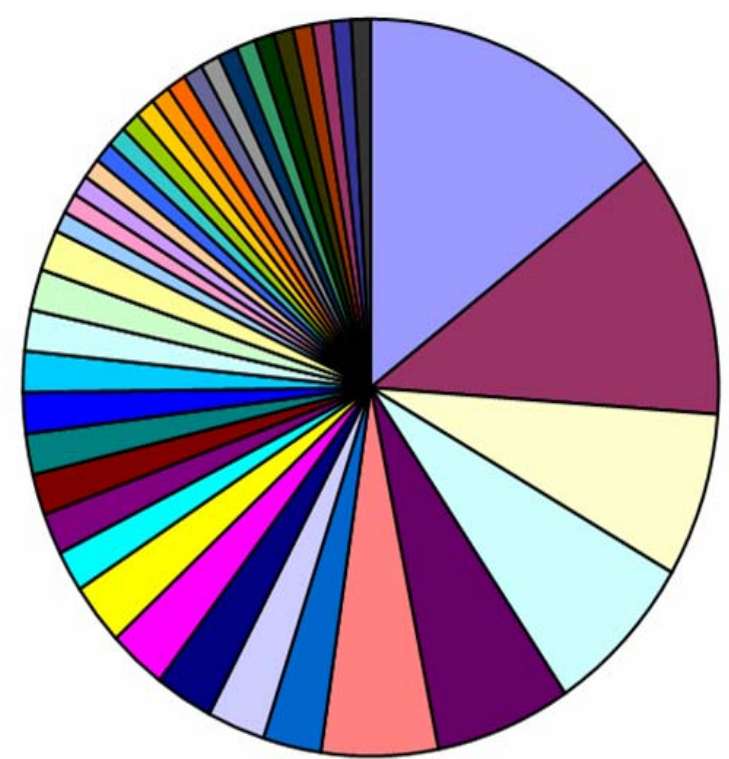

\begin{tabular}{|c|c|c|c|c|c|}
\hline $\begin{array}{l}\text { पAsteraceae } \\
\text { वCistaceae } \\
\text { वCupressaceae } \\
\text { वResedaceae } \\
\square \text { Caprifoliaceae } \\
\square \text { Arecaceae } \\
\square \text { Therebinthaceae }\end{array}$ & 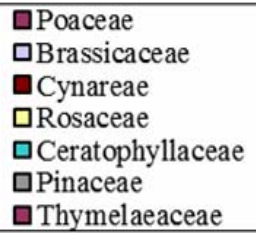 & 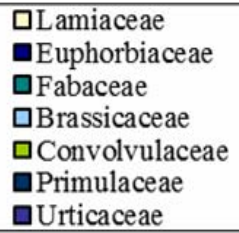 & 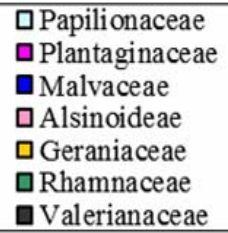 & $\begin{array}{l}\text { QLiliaceae } \\
\text { 口Renonculaceae } \\
\text { QMyrtaceae } \\
\text { 口Araliaceae } \\
\text { QMimoseae } \\
\text { QRutaceae }\end{array}$ & 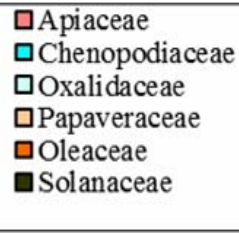 \\
\hline
\end{tabular}

Figure 3. Composition of the Flora by family.

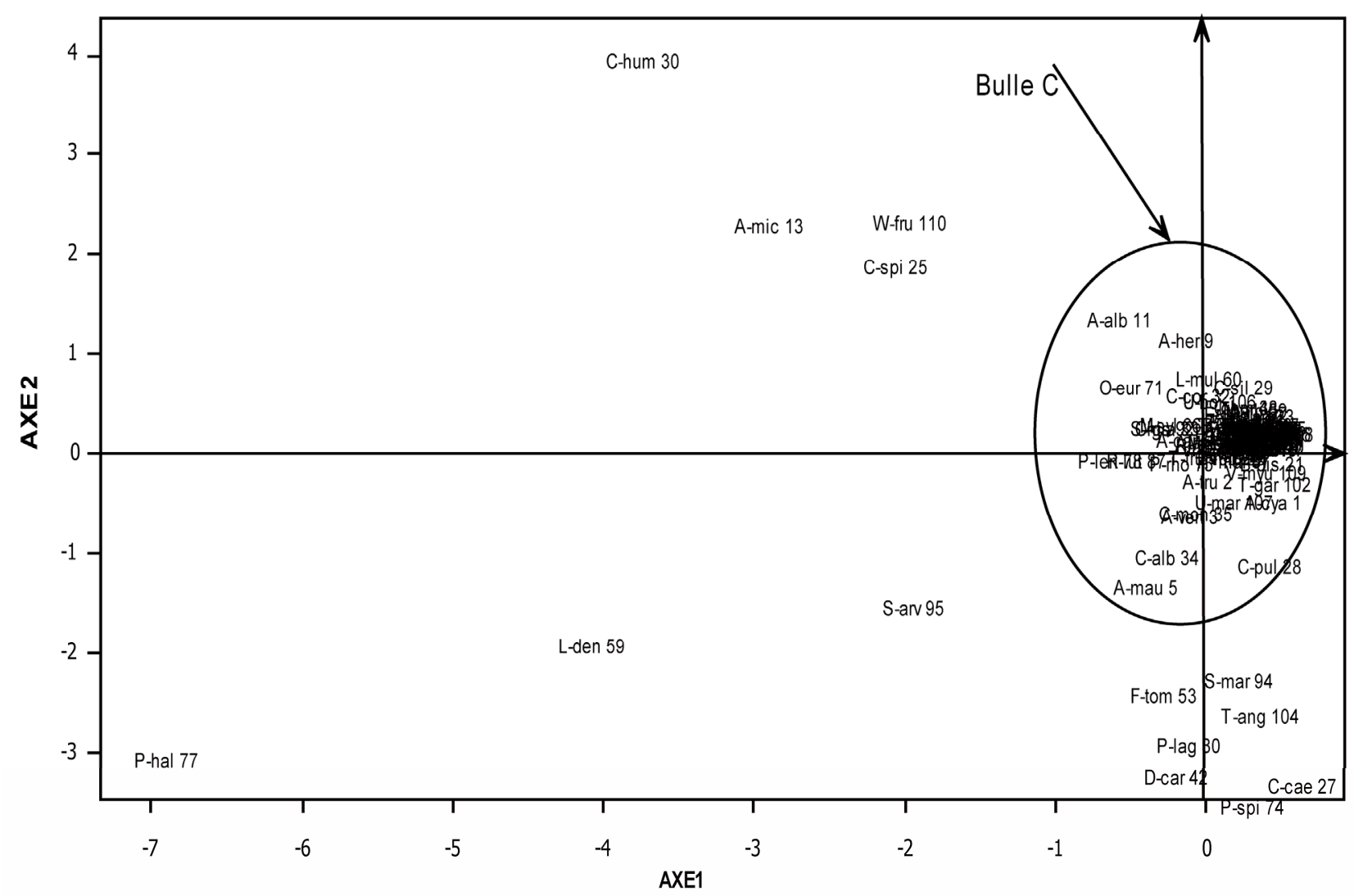

Figure 4. Factorial plan of the species (axis 1 - axis 2). 


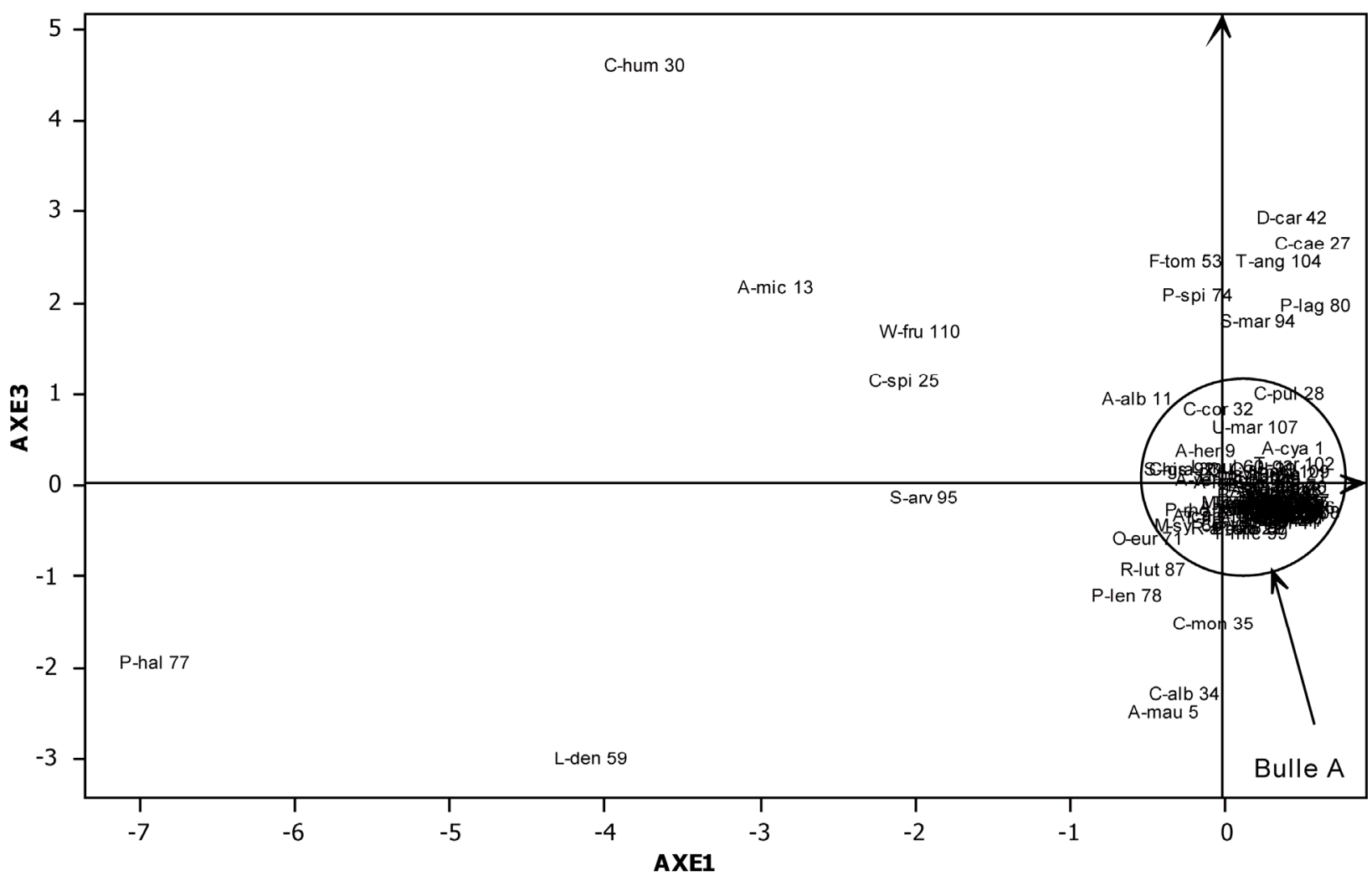

Figure 5. Factorial plan of the species (axis 1 - axis 3).

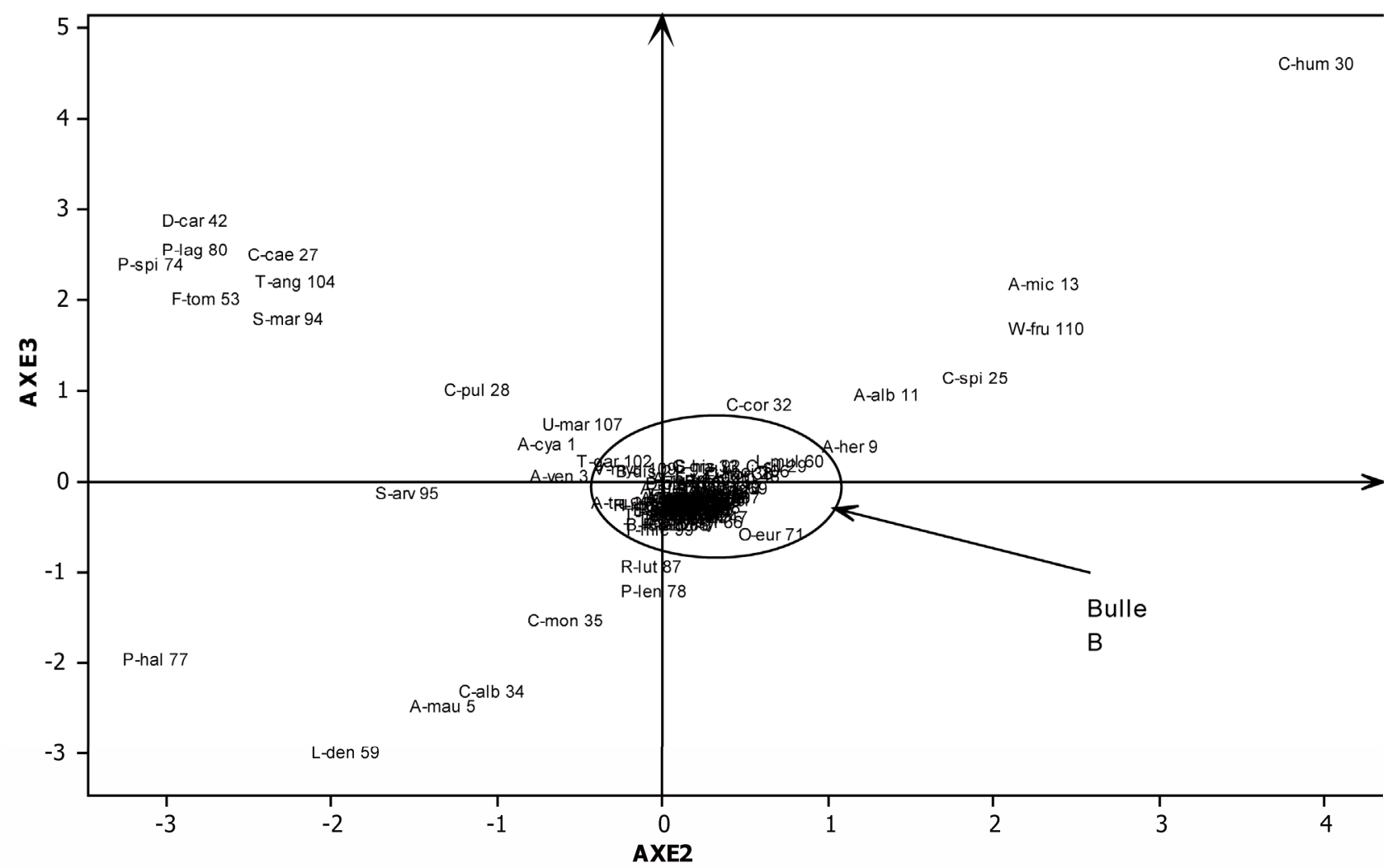

Figure 6. Factorial plan of the species (axis 2 - axis 3). 
Table 3. Contributions of the species for the three axes of FAC.

\begin{tabular}{|c|c|c|c|c|}
\hline Genera/Specie & Code & AXE1 & AXE2 & AXE3 \\
\hline Acacia cyanophilla & A-cya 1 & 0.45382 & -0.46455 & 0.39117 \\
\hline Aegilops truncialis & A-tru 2 & 0.02382 & -0.26934 & -0.23519 \\
\hline Aegilops ventricosa & A-ven 3 & -0.10788 & -0.62239 & 0.06489 \\
\hline Agropyron repens & A-rep 4 & -0.00886 & 0.10994 & 0.04547 \\
\hline Ampelodesma mauritanica & A-mau 5 & -0.39072 & -1.32393 & -2.48101 \\
\hline Anagallis arvensis & A-arv 6 & 0.31103 & 0.0861 & -0.35785 \\
\hline Anthmis maritima & A-mar 7 & 0.4374 & 0.232 & -0.22925 \\
\hline Arenaria emarginata & A-ema 8 & 0.36874 & 0.29701 & -0.15162 \\
\hline Artemesia herba-alba & A-her 9 & -0.12547 & 1.14564 & 0.37507 \\
\hline Asparagus acutifolius & A-acu 10 & 0.28727 & 0.38956 & -0.04663 \\
\hline Asparagus albus & A-alb 11 & -0.56726 & 1.36737 & 0.94943 \\
\hline Asparagus stipularis & A-sti 12 & 0.18636 & 0.20433 & -0.38176 \\
\hline Asphodelus microcarpus & A-mic 13 & -2.89788 & 2.31542 & 2.16988 \\
\hline Asteriscus maritimus & A-mar 14 & 0.21845 & 0.28475 & -0.21197 \\
\hline Atractylis cancellata & A-can 15 & -0.09372 & 0.15887 & -0.33819 \\
\hline Atriplex halimus & A -hal 16 & 0.47117 & 0.1984 & -0.25443 \\
\hline Avena alba & A-alb 17 & 0.44713 & 0.07903 & -0.17135 \\
\hline Avena sterilis & A-ste 18 & 0.40039 & 0.07756 & -0.05919 \\
\hline Bellis annua & B-ann 19 & 0.20229 & 0.31564 & -0.09384 \\
\hline Bellis sylvestris & B-syl 20 & 0.41538 & 0.13842 & -0.35735 \\
\hline Brachypodium distachyum & B-dis 21 & 0.43585 & -0.07193 & 0.11873 \\
\hline Bromus rubens & B-rub 22 & 0.15828 & -0.02407 & -0.48656 \\
\hline Bupleurum lancifolium & B-lan 23 & 0.38244 & 0.40023 & -0.07680 \\
\hline Calendula arvensis & c-arv 24 & 0.22399 & -0.00777 & -0.20059 \\
\hline Calycotum spinosa & C-spi 25 & -2.05936 & 1.8951 & 1.14407 \\
\hline Calycotum vilosa & C-vil 26 & 0.40396 & 0.19332 & -0.21799 \\
\hline Carthamus caeruleus & C-cae 27 & 0.35318 & -2.61485 & 2.42160 \\
\hline Centaurea pullata & C-pul 28 & 0.42311 & -1.11134 & 1.00090 \\
\hline Ceratonia siliqua & C-sil 29 & 0.25623 & 0.69129 & 0.16528 \\
\hline Chamaerops humilis & C-hum 30 & -3.73776 & 3.95036 & 4.60317 \\
\hline Chenopodium album & C-alb 31 & 0.39942 & 0.23747 & -0.30316 \\
\hline Chrysanthemum coronarium & C-cor 32 & -0.04278 & 0.59187 & 0.83827 \\
\hline Chrysanthemum grandiflorum & C-gra 33 & -0.25032 & 0.27159 & 0.18232 \\
\hline Cistus albidus & C-alb 34 & -0.24998 & -1.02746 & -2.30305 \\
\hline Cistus monspeliensis & C-mon 35 & -0.06158 & -0.57878 & -1.51773 \\
\hline Convolvulus altheoIIdes & C-alt 36 & 0.39942 & 0.23747 & -0.30316 \\
\hline Crateagus oxyacantha & C-oxy 37 & 0.39942 & 0.23747 & -0.30316 \\
\hline Cupressus horizontalis & C-hor 38 & 0.27209 & 0.4731 & 0.08064 \\
\hline Cytisus triflorus & C-tri 39 & 0.4048 & 0.23742 & -0.23117 \\
\hline Dactylis glomerata & D-glo 40 & 0.44623 & 0.10199 & -0.02866 \\
\hline Daphne gnidum & D-gni 41 & 0.39064 & 0.07743 & -0.41326 \\
\hline Daucus carota & D-car 42 & 0.35597 & -2.83057 & 2.66443 \\
\hline Echinops spinosus & E-spi 43 & 0.23411 & 0.33892 & 0.00473 \\
\hline Echium vulgare & E-vul 44 & 0.13903 & 0.21342 & -0.42552 \\
\hline Erodium moschatum & E-mos 45 & 0.24088 & 0.0567 & -0.30829 \\
\hline Eryngium triscuspidatum & E-tri 46 & 0.25946 & 0.25672 & 0.02963 \\
\hline Eucalyptus camaldiensis & E-cam 47 & 0.38269 & 0.29212 & -0.39854 \\
\hline
\end{tabular}


Continued

\begin{tabular}{|c|c|c|c|c|}
\hline Eucalyptus gomfocefala & E-gom 48 & 0.24259 & 0.49057 & 0.05502 \\
\hline Euphorbia biumbelleta & E-biu 49 & 0.30966 & 0.21913 & -0.25032 \\
\hline Euphorbia falcata & E-fal 50 & 0.35198 & 0.15472 & -0.34025 \\
\hline Euphorbia segetalis & E-seg 51 & 0.24834 & 0.1357 & -0.19815 \\
\hline Fedia cornucopiae & F-cor 52 & 0.4039 & 0.13001 & -0.16506 \\
\hline Ferula communis & F-com 53 & 0.26736 & -2.64891 & 2.53602 \\
\hline Galactites tomentosa & G-tem 54 & 0.39128 & 0.20528 & -0.25641 \\
\hline Hedera helix & H-hel 55 & 0.42154 & 0.21404 & -0.26713 \\
\hline Helianthemum helianthemoÏdes & H-hel 56 & 0.31814 & 0.33267 & -0.13613 \\
\hline Hordeum maritinum & H-mar 57 & 0.18493 & -0.06561 & -0.25813 \\
\hline Inula viscosa & I-vis 58 & 0.4374 & 0.232 & -0.22925 \\
\hline Lavandula dentata & L-den 59 & -4.0796 & -1.90376 & -2.98715 \\
\hline Lavandula multifida & L-mul 60 & 0.02856 & 0.76887 & 0.21693 \\
\hline Lavandula stoechas & L-sto 61 & 0.42951 & 0.12971 & -0.36223 \\
\hline Lepturus cylindricus & L-cyl 62 & 0.43253 & 0.19179 & -0.27471 \\
\hline Lobularia maritima & L-mar 63 & 0.19312 & 0.20618 & -0.17883 \\
\hline Lonicera implexa & L-imp 64 & 0.34417 & 0.14906 & -0.36737 \\
\hline Malva aegyptiaca & M-aeg 65 & 0.3391 & 0.21482 & -0.30730 \\
\hline Malva sylvestris & M-syl 66 & -0.2246 & 0.30526 & -0.44663 \\
\hline Marrubium vulgare & M-vul 67 & 0.33567 & 0.40741 & -0.17231 \\
\hline Medicago arbicularis & M-arb 68 & 0.42921 & 0.2745 & -0.19062 \\
\hline Medicago arborea & M-arb 69 & 0.33095 & 0.4429 & -0.07549 \\
\hline Muscari neglectum & M-neg 70 & 0.10312 & 0.12806 & -0.19087 \\
\hline Olea europea & O-eur 71 & -0.48355 & 0.67223 & -0.58918 \\
\hline Oxalis cernua & O-cer 72 & 0.41325 & 0.15157 & -0.18393 \\
\hline Oxalis corniculata & O-cor 73 & 0.41074 & 0.28117 & -0.21930 \\
\hline Pallenis spinosa & P-spi 74 & 0.11494 & -2.87169 & 2.54170 \\
\hline Papaver rhoeas & P-rho 75 & -0.15818 & -0.08724 & -0.26326 \\
\hline Phalaris bulbosa & P-bul 76 & 0.44623 & 0.10199 & -0.02866 \\
\hline Pinus halepensis & P-hal 77 & -6.90122 & -3.04985 & -1.96102 \\
\hline Pistacia lentiscus & P-len 78 & -0.62697 & -0.04148 & -1.20626 \\
\hline Plantago albicans & P-alb 79 & 0.17049 & 0.09675 & -0.48540 \\
\hline Plantago lagopus & P-lag 80 & 0.33649 & -2.81283 & 2.55966 \\
\hline Plantago ovata & P-ova 81 & 0.21078 & 0.33528 & -0.19961 \\
\hline Raphanus raphanistum & R-rap 82 & 0.33877 & 0.10743 & -0.23550 \\
\hline Renonculus arvensis & R-arv 83 & 0.17536 & 0.05007 & -0.30958 \\
\hline Renonculus paludocus & R-pal 84 & 0.34327 & 0.28538 & -0.11570 \\
\hline Renonculus repens & R-rep 85 & 0.29391 & 0.08912 & -0.24234 \\
\hline Reseda alba & R-alb 86 & 0.01224 & 0.08717 & -0.47137 \\
\hline Reseda lutea & R-lut 87 & -0.45393 & -0.06321 & -0.93147 \\
\hline Rosa sempervirens & R-sem 88 & 0.4115 & 0.18782 & -0.31219 \\
\hline Rosmarinus officinalis & R-off 89 & 0.35637 & 0.2571 & -0.24194 \\
\hline Ruta chalepensis & R-cha 90 & 0.36188 & 0.23574 & -0.24579 \\
\hline Salvia verbenaca & S-ver 91 & 0.44905 & 0.22183 & -0.29046 \\
\hline Scolymus hispanicus & S-his 92 & -0.28287 & 0.27497 & 0.17507 \\
\hline Selinopsis montana & S-mon 93 & 0.35701 & 0.28229 & -0.18092 \\
\hline Silybum marianum & S-mar 94 & 0.22596 & -2.25076 & 1.79107 \\
\hline Sinapis arvensis & S-arv 95 & -1.93651 & -1.53612 & -0.12741 \\
\hline Smilax aspera & S-asp 96 & 0.36188 & 0.20346 & -0.32490 \\
\hline Solenanthus lanatus & S-lan 97 & 0.39807 & 0.1781 & -0.37353 \\
\hline
\end{tabular}




\begin{tabular}{ccccc} 
Continued & \multicolumn{1}{c}{} \\
\hline Spartium junceum & S-jun 98 & 0.32713 & 0.28667 & -0.12159 \\
Taraxacum microcephalum & T-mic 99 & 0.17455 & -0.00971 & -0.53549 \\
Teucrium frutecans & T-fru 101 & -0.01543 & -0.01932 & -0.36234 \\
Thapsia garganica & T-gar 102 & 0.45923 & -0.27738 & 0.22353 \\
Thymus algeriensis & T-alg 103 & 0.32187 & 0.14365 & -0.25785 \\
Trifolium angustifolium & T-ang 104 & 0.35814 & -2.60473 & 2.43962 \\
Trifolium nigrescens & T-neg 105 & 0.40362 & 0.2656 & -0.20408 \\
Ulex boivini & U-boi 106 & 0.09589 & 0.54508 & 0.12108 \\
Urginea maritima & U-mar 107 & 0.1957 & -0.47672 & 0.63100 \\
Urtica membranacea & U-men 108 & 0.44905 & 0.22183 & -0.29046 \\
Vulpia myuros & V-myu 109 & 0.39663 & -0.1611 & 0.14071 \\
Withania frutescens & W-fru 110 & -1.95393 & 2.32502 & 1.69473 \\
Ziziphus lotus & Z-lot 111 & 0.4309 & 0.13791 & -0.33385
\end{tabular}

Table 4. Eigenvalues and percentage of inertia for the first three axes of FAC. "species".

\begin{tabular}{cccc}
\hline Axe & $\mathbf{1}$ & $\mathbf{2}$ & $\mathbf{3}$ \\
\hline Eigenvalue & 17.606 & 5.485 & 4.413 \\
Rate of inertia & 35.2 & 11.0 & 8.8 \\
\hline
\end{tabular}

\subsection{Analyzes Factorial Plan}

\subsubsection{Factorial Plan (Axis 1 - 3) (Figure 5)}

Interpretations of axis 1:

- Eigenvalue: 17.606;

- Rate of inertia: $35.2 \%$.

On the factorial plan $(1-3)$ : we can study the position of the species on the two sides of the axis 1 (Table 5), of the positive side most extreme shows a regrouping of the statements of species which represents a degraded matorral, containing Chamaerops humilis, Asphodelus microcarpus, Withania frutescens, Calycotome spinosa, Asparagus albus. The proliferation of these species, generally thorny in this environment, indicates its degradation by the anthropozoic agents. Bouazza and Benabadji [6], indicate that, the anthropozoogene effect allowed an expansionist evolution of the species scorned by the cattle.

The negative side of axis 1 , presents the Pinus halepensis, accompanied with a low formation which consists of: Lavandula dentata, Sinapis arvensis, Ampelodesmamau ritanicum. Indicate the instability of the environment. It is a matorral of Pinus halepensis (stage of degradation).

In the center of the factorial design, we have localized the formation of a bull "A". It is composed of the rest of the whole of the species which do not seem to react to any ecological parameter. Let us note that the factorial map (Axis 1 - 2) (Figure 4) is almost identical to the factorial map (Axis 1 - 3) interpreted previously.
Table 5. Taxa with high contributions for axis 1 with FAC.

\begin{tabular}{cc}
\hline Positive side of axis 1 & Dimensioned negative of axis 1 \\
\hline Chamaerops humilis & Pinus halepensis \\
Asphodelus microcarpus & Lavandula dentata \\
Withania frutescens & Sinapis arvensis \\
Calycotome spinosa & Ampelodesma mauritanicum \\
Asparagus albus & \\
\hline
\end{tabular}

\subsubsection{Factorial Plan (Axis 2 - 3) (Figure 6)}

Interpretations of axis 2 :

- Eigenvalue: 5.485

- Rate of inertia: $11 \%$.

The positive side of axis 2 , we noticed two groupings of species: The 1st group consists of Chamaerops humilis, Chrysanthemum coronarium, Asphodelus microcarpus, Withania frutescens, Calycotome spinosa, Asparagus albus, Ulex boivini. This meant a degradation of the vegetation. Quézel et al. [32], specifies that the installation of these species informs about the manifestation of some degradation (Table 6).

The 2nd group is composed of Ferula communis, Daucus carota, Carthamus caeruleus, Plantago lagopus, Trifolium angustifolium, Silybum marianum, Pallenis spinosa. It is a degraded environment occupied by xeric species that are more resistant to environmental conditions which became increasingly severe. These plants grow in a semiarid bioclimatic environment. Their presence also shows certain degradation, marked by the presence of species such as: Urginea maritima, Asphodelus aestivus, Ferulacommunis (Table 6).

The negative side, we have the following species: $P i-$ nus halepensis, Cistus albidus, Ampelodesma mauritanicum, Lavandula dentata, Aegilops ventricosa. It is a matorral in the process of degradation. We have also the formation of a bull "B" in the center of the two axes (2 and 3) which is also made up of the remaining species 
Table 6. Taxa with high contributions for axis 2 with FAC.

\begin{tabular}{cc}
\hline Positive side of axis 2 & Dimensioned negative of axis 2 \\
\hline 1st group & \\
Chamaerops humilis & \\
Chrysanthemum coronarium & \\
Asphodelus microcarpus & \\
Withania frutescens & \\
Calycotome spinosa & Pinus halepensis \\
Asparagus albus & Cistus albidus \\
Ulex boivini & Ampelodesma mauritanicum \\
2nd group & Lavandula dentata \\
Ferula communis & Aegilops ventricosa \\
Daucus carota & \\
Carthamus caeruleus & \\
Plantago lagopus & \\
Trifolium angustifolium & \\
Silybum marianum & \\
Pallenis spinosa & \\
\hline
\end{tabular}

which do not represent any correlation with the ecological parameters (Table 6).

\section{Conclusion}

The correspondence analysis, realized on the species inventoried in the area of Beni Saf, makes it possible to highlight the ecological gradients and to confirm that the bioclimatic and anthropozoic factors explain the great part of the information brought by the various axes. The position of Pinus halepensis is a bit special on the level of the various factorial designs. Its space position, explains us to some extent, that this resinous species, introduced into the zone of study by the operations of afforestation, is badly integrated in some stations due to a high anthropozoic pressure, and a climatic and edaphic aggressiveness unfavorable with the regular development of this species which are found in a fragile situation, vis-a-vis to diseases and decay.

Indeed, these conditions lead this vegetation to bushy formations consisting of more resistant species, colonizing the natural environment, and replace the ligneous family, which have become too fragile. These species include: Chamaerops humilis, Ampelodesma mauritani cum, Calycotome spinosa, Chrysanthemum coronarium, Asphodelus microcarpus, Urginea maritima, Ferula communis. Calycotome spinosa, Asparagus albus, etc., justifying also the degradation of the natural environment $[29,32]$. In front of this critical situation, the protection and valorization are the ultimate means to revitalize the structure of this vegetation which are threatened.

Stands of Pinus halepensis in the area of Beni Saf, constitute transitory formations evolving normally to the structures of the matorral type to Oleo-mastic tree. This vegetation still remains under the anthropozoic pressure, which causes the degradation and the advanced regression of the natural environment.
Concerning, the Eucalyptus camaldiensis (introduced into the zone of study, by the afforestation), after the factorial correspondence analysis, does not seem to represent any correlation with the ecological parameters. This explains its adaptation to the natural environment, including the climatic conditions which are more or less severe.

The objectives of forest management and the breeding are complementary: the protection of forests against the overgrazing and fires, the conservation of the inheritance and the biodiversity, in addition to a livestock production which takes part in the economic development of the area. This system has many advantages, in particular the structure of the territory with dual-use developments, associating specialized surfaces for pastures, improved by fodder plantations, available in particular in the periods of strong food need, and a strict setting to protect the natural stands to reconstitute themselves and be maintained. Concerning the bovine breeding intensified for the dairy production, we propose the creation of farms, which most of their surface will be reserved for the fodder cultures and food for the cattle.

\section{REFERENCES}

[1] Médail, F. and Quézel, P. (1997) Hot-spot analysis for conservation of plant biodiversity in the Mediterranean basin. Annal of theMissouri Botanical Garden, 84, 112-127.

[2] Médail, F. and Diadema, K. (2006) Biodiversité végétale méditerranéenne et anthropisation: Approche macro et micro-régionales. Annales de Géographique, 651, 618640.

[3] Mazour, M. and Morsli, B. (2004) L'impact combiné de la couverture végétale et de l'érosion sur l'infiltration et l'érodibilité du sol en parcelles expérimentales (type Wischmeier) dans les bassins versants du Nord-Ouest Algérien. Lab; CES, Dept Foresterie, Fac. Des Sci. Univ. Tlemcen. Algerie. 249.

[4] Barbero, M., Loisel, R. and Quezel, P. (1990) Les apports de la phytoécologie dans l'interprétation des changements et perturbation induite par l'homme sur les écosystèmes forestiers méditerranéens. Forêt Méditerranéenne XII, 3, 194-216.

[5] Merioua, S.M. (2007) Aménagement et approche cartographique des peuplements végétaux dans la région de Béni Saf (Nord de Tlemcen_Oranie) Thèse de magistère. Department of Forest, University of Tlemcen, Tlemcen, 184.

[6] Bouazza, M. and Benabadji, N. (1998) Composition floristique et pression anthropozoïque du sud-Ouest de Tlemcen. Revue sciences et technologies, 10, 93-97.

[7] Floret, C. and Pontanier, R. (1982) L'aridité en Tunisie présaharienne. Climat, sol, végétation et aménagement. Mémoire de thèses. Travaux et documents de l'O.R.S.T.O.M., Paris, 544.

[8] Delabraze, P. and Valette J.C. (1974) Etude de l'inflam- 
mabilité et combustibilité. Consultation FAO sur les incendies de forêts en méditerranée.

[9] Le Houerou, H.N. (1980) L'impact de l'homme et de ses animaux sur la forêt méditerranéenne. Forêt Méditerranéenne II, 2, 155-174.

[10] Tatoni, T.M. and Barbero, M. (1990) Approche écologique des incendies en forêts méditerranéennes. Ecologia Mediterranea XII, 3/4, 78-99.

[11] Pardé, J. and Bouchon J. (1988) Dendrométrie. 2nd Edition, Ecole National du Génie Rural, des Eaux et Forets, Nancy, 327.

[12] Frontier, S. (1983) Stratégie d'échantillonnage en écologie. Edit. Masson et Cie. Coll. d'Ecol. Press, University De Laval, Québéc.

[13] Braun-Blanquet, J. (1951) Pflanzensoziologie Grundzuge der vegetetions Kunde (2eme Ed) Springer, Vienne. Ed. 2, Autriche, 631.

[14] El Hamrouni, A. (1992) Végétation forestière et préforestière de la Tunisie: Typologie et élément pour la gestion. Thèse Doct. Es. Sci. Univ. Aix Marseille III, 220.

[15] Gehu, J.M. (1987) Données sur la végétation littorale de la Crête (Grèce). Ecologia méditerranée XIII, 1-2, 93105.

[16] Gounot, M. (1969) Méthodes d'étude quantitative de la végétation. Ed. Masson, Paris, 314.

[17] Cornier, T. (2002) La végétation alluviale de la Loire entre le Charolais et l'Anjou: essai de modélisation de l'hydro système. Thèse de Doc, Etat. Univ. Francios Rabelais, Tome, 1, 227.

[18] Cordier, B. (1965) L'analyse factorielle des correspondances. Thèse Spéc. Univ. Rennes, 66.

[19] Benzecri, J.P. (1973) L'analyse des données. Tome 1. La taxonomie. Ed. Dunod, Paris, 675.

[20] Fenelon, J.P.(1981) Qu'est ce que l'analyse de données? Paris, Lefonen.

[21] Roux, G. (1967) A propos de quelques méthodes de clas- sification en phytosociologie. Revue de Statistique Appliquée, 15, 2.

[22] Lacoste, A. and Roux M. (1972) L'analyse multidimensionnelle en phytosociologie eten écologie. Application à l'étage subalpin des Alpes maritimes. Analyses des données floristiques. Oecologia Plant, 7, 125-146.

[23] Escofier, B. and Pages J. (1990) Analyses factorielles simples et multiples. 2nd Edition, Dunod, Paris, 274.

[24] Stebbins, G.L. (1952) Aridity as a stimulus to plant evolution. American National, 86.

[25] Stebbins, G.L. and Major J. (1965) Endemism and Speciation in California Flora. Ecol.

[26] Sauvage, Ch. (1961) Recherches géobotaniques sur les subéraies marocaines. Tv. Inst. Sc. Chérifien, Rabat.

[27] Gaussen, H. (1963) Ecologie et phytogéographie. In Abbayes, 952-972.

[28] Negre, R. (1966) Les Thérophytes. Mem. Soc. Bot. France, 92-108.

[29] Daget, Ph. (1980) Un élément actuel de la caractérisation du monde méditerranéen: Le climat-nat. Monsp: H-S: 101-126.

[30] Quezel, P. (2000) Réflexions sur l'évolution de la flore et de la végétation au Maghreb méditerranéen. Ed. Ibis. Press, Paris.

[31] Loisel, R. and Gomila, H. (1993) Traduction des effets du débroussaillement sur les écosystèmes forestiers et pré forestiers par un indice de perturbation. Annales de la Société des Sciences Naturelles et d'Archéologie de Toulon et du Var, 123-132.

[32] El Hamrouni, A. (1992) Végétation forestière et prés forestière de la Tunisie: Typologie et élément pour la géstion; Thèse. Doct. Es. Sc. Univ. Aix-Marseille, 220.

[33] Quezel, P., Barbero, M., Benabid, A. and Rivas-Martinez, S. (1992) Contribution à l'étude des groupements forestiers et pré-forestiers du Maroc Oriental. Studia Botanica, 10/57-90, Salamanca. 